\title{
6
}

\section{DEVELOPING INTERCULTURAL COMMUNICATION AND INTERCULTURAL AWARENESS IN THE EFL CLASSROOM}

\author{
PROMOVENDO A COMUNICAÇÃO E CONSCIÊNCIA \\ INTERCULTURAIS NA SALA DE AULA DE INGLÊS \\ COMO LÍNGUA ESTRANGEIRA (ILE)
}

\author{
Lili Cavalheiro' \\ Universidade de Lisboa, Portugal
}

\begin{abstract}
Throughout multiple regions around the world, waves of migrants and refugees search for better and safer living conditions. As a result, classrooms are becoming increasingly multicultural and multilingual, with many teachers feeling challenged when faced with this 'new' reality. Being English the most commonly shared language around the world, the English as a Foreign Language (EFL) classroom can be a 'safe' place where dialogue and intercultural communication are fomented. Not only can it facilitate the integration of migrant/refugee students, but it can also contribute to expanding learners' (inter)cultural awareness and knowledge of how English may be used by multiple speakers (native and non-native) in diverse settings. In light of this, it is imperative that educators develop more inclusive English-language lessons that help break down barriers and taboos, in terms of language and culture. In order to achieve this, however, it is vital that these issues be developed at the beginning of any teacher training. Bearing this in mind, this paper begins by presenting the concept of English as a Lingua Franca and intercultural communication and follows up by reflecting upon how the traditional EFL classroom should to be reconsidered in light of today's international role of English. Taking into account the specific growing multicultural/multilingual Portuguese context, the last section of this paper presents how these issues are developed in two pre-service MA programs in English Language Teaching at the University of Lisbon, and also how student teachers have integrated ELF-related activities/resources in their practicum, along with a commentary on their learners' reactions.
\end{abstract}

Keywords: Intercultural Communication; Intercultural Communicative Competence; Intercultural Awareness; English Language Teaching; Pre-service teacher education.

1 lilicavalheiro@campus.ul.pt

30 № 65, NÚM. ESP.| 2020, Salvador: pp. 30-48 
Resumo: Em várias regiões do mundo, as vagas de migrantes e refugiados procuram por melhores condições de vida e segurança. Consequentemente, as salas de aula estão a tornar-se cada vez mais multiculturais e multilinguísticas, com muitos professores a encontrarem desafios perante esta "nova" realidade. Dado o Inglês ser a língua comum partilhada no mundo, a sala de aula de Inglês como Língua Estrangeira pode ser um espaço "seguro" onde o diálogo e a comunicação intercultural são fomentados. Não só a sala de aula pode facilitar a integração dos estudantes migrantes/refugiados, como também pode contribuir para expandir a consciência (inter)cultural dos alunos, em geral, e, em específico, informar sobre o modo como o Inglês é utilizado por múltiplos falantes (nativos e não-nativos) em diversos contextos. Tendo isto em conta, é imperativo que os professores aprendam a preparar aulas de Inglês que sejam mais inclusivas e que contribuam para quebrar barreiras e tabus, a nível da cultura e da língua. Por isso, este artigo estuda a importância do desenvolvimento destas questões desde a formação inicial de professores. Considerando o crescente contexto multicultural/multilinguístico português, a última secção deste artigo apresenta não só o modo como estas questões são desenvolvidas em dois programas de Mestrado em Ensino de Inglês na Universidade de Lisboa, mas também a experiência dos formandos durante a sua prática de ensino supervisionada onde implementaram várias atividades e materiais didáticos que exploram a questão do inglês como língua internacional.

Palavras-Chave: Comunicação Intercultural; Competência Comunicativa Intercultural; Ensino de Língua Inglesa; Formação Inicial de Professores.

\section{INTRODUCTION}

Globalization, migration and the relatively recent waves of refugees seeking better and safer living conditions have contributed not only to political and economic changes in many countries, but also to changes at a cultural, linguistic and societal level (COUPLAND, 2010; DEWEY, 2007). Therefore, effective communication plays an essential role for successful integration and interaction. Considering the array of linguistic and cultural backgrounds of (im)migrants and refugees, many of the times it is difficult to communicate in the local language of a specific country, especially when one has recently arrived, either for a temporary amount of time or to establish themselves there. In these situations, more often than not, English functions as a lingua franca, as the common medium of communication par excellence, especially due to two essential factors. Firstly, it is the most taught language today at a global level and secondly, because it is the most widely learnt language, the amount of non-native English speakers has by far exceeded the number of native speakers (CRYSTAL, 2003; MCKAY; BOKHORST-HENG, 2008). As a result, according to Baker (2018, p. 25), communication in English "is presently likely to be the most common medium of intercultural communication" shared by speakers of different linguacultural backgrounds, who express, accommodate and negotiate their cultural and linguistic differences. 
The use of English as a lingua franca (ELF) or international language (EIL) for successful intercultural communication is thus a central issue that deserves the attention of English language teachers around the world. On the one hand, given the growing number of multicultural and multilingual students, the English as a foreign language (EFL) classroom can facilitate the integration of migrant students by promoting dialogue and intercultural exchanges, especially when considering that in many circumstances English is the shared language between those students (who have likely already learned English in their home countries) and their local classmates. On the other hand, English classes in general can and should go beyond the traditional American/British paradigm, so as to broaden learners' (inter)cultural awareness of how English is used by multiple speakers (native and non-native) in diverse settings, preparing them for real-world interactions once outside school (e.g. academia, business, travel, sports, internet/technology).

In light of these issues, it is paramount that EFL educators create more inclusive and comprehensive lessons to help break down barriers and taboos regarding language and culture. To do so, they need to be acquainted with the ELF literature (e.g. JENKINS, 2007, 2015; SEIDLHOFER, 2011), intercultural awareness (e.g. BAKER, 2011, 2018) and intercultural communication (e.g. ALPTEKIN, 2002; BYRAM, 1997; KRAMSCH, 2001), to name some of the key notions involved. These issues may be developed with in-service teachers (e.g. BAYYURT; SIFAKIS, 2017; LOPRIORE, 2018; SIFAKIS; BAYYURT, 2015), as well as with pre-service teachers (e.g. KEMALOGLU-ER; BAYYURT, 2018; SIQUEIRA, 2018) who are beginning their training and have a close tie with the university, at a more theoretical and academic level, and the local schools, where they have a more practical hands-on approach with the cooperating teachers and learners.

Bearing this in mind, this paper begins by briefly discussing the notions of ELF and intercultural communication, so to afterwards reflect upon how the EFL classroom may be reconsidered in light of today's global society. Lastly, an example is provided of how these issues are explored in two MA programs in English Language Teaching at the University of Lisbon. Not only are the theoretical issues discussed, but examples are also given of what student teachers (STs) have done with their learners and how these react to a more interculturally ELF-aware approach. 


\section{ELF AND INTERCULTURAL COMMUNICATION}

Several working definitions for ELF have been proposed by researchers throughout the years. In some initial cases, it was only applied to those who did not have English as a first language, therefore excluding native speakers from the equation (e.g. FIRTH, 1996); however, more recently, native speakers have been contemplated as well (e.g. JENKINS, 2007; MAURANEN, 2012; SEIDLHOFER, 2011). Mauranen (2018, p. 8), for instance, has defined ELF as the English that "is spoken in situations with widely varying combinations of participants, including first-language speakers of different varieties." She also goes on to emphasize that English is a language that may be spoken by anyone in a variety of different scenarios, both in person or electronically through the Internet. As she puts it:

ELF is not just a contact language where English is a domestic language or otherwise especially salient in a given community, but a non-local lingua franca, the means of communicating between people from anywhere in the world. Neither is its global weight restricted to elite usages in politics, international business or academia, but it is also employed by tourists, migrant workers, asylum seekers and just anyone in their daily lives over digital media. There is not even need to move around physically to be in contact with English. (MAURANEN, 2018, p. 7)

Consequently, according to Baker (2015, p. 43), “ELF is by definition intercultural in nature since ELF communication is typically defined as involving speakers from different linguacultures." ELF exchanges therefore reflect participants' multilingual and multicultural backgrounds, as they recognize not only their linguistic and cultural differences, but also the importance of interaction and negotiation for successful intercultural communication (SCOLLON; SCOLLON, 2001; ZHU, 2014).

Thus, effective communicative exchanges go beyond native-like competence in lexis, phonology or syntax, to include a variety of communicative and pragmatic strategies, such as accommodation, code-switching, explicitness, pre-empting misunderstanding or repetition (JENKINS ET AL., 2011). Although these strategies may sometimes be associated with poor linguistic proficiency, they are, in fact, examples of pragmatic competence when employed by intercultural speakers who adapt their speech according to the communicative situation in question and its participants.

As for the issue of culture and identity, Byram's notion of intercultural communicative competence (ICC) (1997) has been fundamental when taking into 
account an individual's understanding of his/her own culture and that of others, as well as how communication is shaped by it. By adopting a critical approach to culture and communication, it is necessary to have an open disposition to discover and acknowledge the differences that occur in communication, and to mediate between different communicative practices and cultural groups (BYRAM, 1997).

Despite its significant contribution, ICC has sometimes been criticized for its nationally centered outlook on culture, so Baker $(2011,2015,2018)$ has put forth the notion of intercultural awareness (ICA), especially in intercultural communication through ELF. Although ICA shares several common features with ICC, namely the attitudes, knowledge and skills necessary for intercultural communication, its primary focus does not fall on national perceptions of language and culture. According to Baker (2018), since it is impossible to foresee all the potential communicative scenarios one will engage with in English, it is unfeasible to think of a detailed list of features for ICA. Instead, only broad areas of awareness may be suggested, as he mentions:

These broad areas include different levels of awareness moving from a general or basic awareness of communication as a cultural practice, to a more critical awareness of varied intercultural communicative practices and finally an advanced level of intercultural awareness where flexibility, dynamism and complexity are the norm (Baker, 2011, 2015). (BAKER, 2018, p. 33)

In this sense, because most communicative situations in English are characterized for their international, diverse and fluid nature, communication, culture and identity will inevitably be perceived as adaptable, constructed and negotiable. The issue that may remain however is: how do we become successful intercultural communicators through English?

\section{RETHINKING THE EFL CLASSROOM}

The EFL classroom has largely been characterized as a space for learning a language that is associated not only with a specific linguistic standard, but also with a set of cultural values, generally British and/or American. However, nowadays, it is increasingly difficult to establish a link between certain languages and cultures, particularly at a national level in intercultural communication (BAKER, 2018). This is especially the case with communicative exchanges in 
English, in which individuals may not identify with or refer to a specific L1 culture. Llurda (2018) further reiterates this idea when he emphasizes the transition from learning English to connect with a particular native target, to acquiring English as a "language of communication" and "tool for intercultural communication". As he puts it:

Learning English no longer aims at communicating with a particular group of native people situated in a given local community. It involves learning a language of communication in different communicative situations among very diverse and far distant communities from anywhere in the world, and it therefore is an invaluable tool for intercultural communication. (LLURDA, 2018, p. 519)

This becomes even more relevant when considering: 1) students interact mostly with other non-native speakers both in and outside of the classroom and 2) in multilingual/multicultural classrooms where (im)migrant/refugee students are present, English is usually the common denominator through which they are able to express themselves and contact with each other.

Bearing this in mind, it is important to rethink and reflect upon which English and which cultures should be taught in the EFL classroom. Although teachers may recognize the diversity and fluidity associated with the use of English across different domains (e.g. educational, social or professional/academic), the issues that many times remain, according to Leung and Lewkowicz (2018, p. 69), are: “[...] how do we deal with the multiple and always emergent and malleable language norms and practices? And how do teaching approaches and materials cope with this flux?" As for the issue of culture, Siqueira (2016, p. 200) also mentions that "the challenge for the practitioner is to find out 'how' to really take culture as something intrinsic, inherent to the plural linguistic system he/she is teaching and, in a proactive way, make good use of it."

In order for EFL teachers to consider these issues, it is fundamental that they not only have a more flexible view of language, in which competence is seen from a more pluralistic approach, but that they also take a careful and closer look at the needs of their learner groups, and reflectively examine and reflect upon their classroom practices and educational values (LEUNG; LEWKOWICZ, 2018). Professional training, both at a pre-service and in-service level, therefore plays a key part in raising (future) teachers' awareness about these issues as well as providing them the confidence to adjust their classroom practices and select additionally more appropriate materials. 
Various authors have put forth suggestions about what should be explored to prepare more ELF-aware teachers; however, due to the lack of space, only some are presented here. Sifakis (2009), for instance, takes into account the Greek context, nevertheless, the issues raised may be applied in many other contexts. One of the first aspects he highlights is the need for teachers to recognize "the communication value of ELF-related accommodation skills" (SIFAKIS, 2009, p. 236), such as paraphrasing, making repairs or rephrasing. These skills play a fundamental role in both teachers and learners feeling empowered as successful intercultural communicators, rather than deficient users who have not achieved or mastered native-speaker proficiency. Another relevant issue to be encouraged among EFL teachers is the promotion of action research projects that take into account different learners' cultural identities, so to "alleviate negative stereotypical attitudes about immigrants" (p. 236). Besides the in-classroom context, Sifakis likewise refers to the use of modern technology. By providing technological training, teachers can take advantage of the different websites and apps that allow learners to establish additional links with nonnative speaker learners in other countries, hence promoting change in the traditional EFL classroom and stimulating real-life intercultural communication.

More recently, Llurda (2018) has proposed similar ideas to what Sifakis (2009) put forth. According to Llurda, instead of focusing on mastering nativespeaker norms, importance should instead be given to communication. However, in order for communication to be successful, it is imperative that learners not only come into contact with different varieties of English to raise their awareness and understanding, but that they also focus on "a more limited range of linguistic elements" (p. 527) that will maximize intelligibility at a productive international level. If teachers are to also consider the growing multilingual EFL context, Llurda emphasizes the use of multilingual resources to reach learners' language goals more successfully.

This latter aspect may raise some difficulties for teachers, especially since Leung and Lewkowicz (2018) believe teachers require more training to confidently adapt or select appropriate materials for their learners' needs. In view of this, encouraging an in-depth critical textbook analysis may help teachers "to engage in reflexive examination of their own classroom practice and educational values in relation to students' language learning needs" (LEUNG; LEWKOWICZ, 2018 , p. 70). By acquiring the know-how and skills to analyze structure and content, in terms of language and culture, teachers can subsequently make more informed decisions that will lead to effective change in EFL classrooms. 
Lastly, regarding the concept of culture and how it may be integrated, this is an area that is generally not fully developed in teacher education programs and that is also not given much importance to in the classroom, especially when the main focus is on the target culture. However, when culture is in fact explored, a large-culture approach is usually adopted from a stereotypical point of view, in which national cultures are confronted (e.g. How would an American and an Italian react in situation $X$ ) and the learners' own cultures are most of the time neglected in favor of other English-speaking cultures. This is evident when analyzing different internationally or even locally-produced coursebooks and ELT materials, which tend to take on such an approach.

Nevertheless, if the aim is to promote greater intercultural awareness, instead of simply focusing on large culture, a small-culture approach can be promoted as well, where attention is given to fostering effective intercultural multilingual communication; hence, encouraging interpersonal interactions between people from different cultural backgrounds. In order to become a competent speaker, it is therefore important learners understand that each communicative scenario is different and that it is necessary to consider the individual speaker with his/her own culture, experiences and identity. Bearing this in mind, large culture can play a central role alongside small culture because of its impact in interpersonal communicative situations. By being aware of how different cultures act and react, speakers can consider their responses accordingly, which will consequently influence the successfulness of their interactions. Taking into consideration the several issues here mentioned, if teachers receive adequate training they will not only become more aware of their own attitudes and practices regarding language and culture, but they will also be able to create more authentic activities that promote reflection and actual intercultural communication in the classroom. By doing so, change can happen in the EFL classroom with learners becoming more aware of their attitudes and identity.

\section{THE STUDY}

Fomenting intercultural communication and intercultural awareness in the EFL classroom is increasingly important as schools are becoming more and more multilingual and multicultural, and Portugal is no exception. According to data from 2018, there are over 180 different nationalities in Portugal, mainly in the Algarve (9.3\%) and Lisbon (7.6\%) regions. In schools, in the 2016-2017 
academic year, a total of 38,712 foreign students were enrolled from basic to secondary education (OLIVEIRA; GOMES, 2017), a 5.7\% increase in comparison to the previous academic school year. When analyzing the top ten nationalities (Chart 1), it is possible to observe that a significant number of students come from Brazil and African countries where Portuguese is an official language, but there are also many students from European countries, especially Eastern European. Among the top ten countries, only the United Kingdom is an Englishspeaking country.

Chart 1. Number of foreign students enrolled from basic to secondary education in the 2016-2017 school year

\begin{tabular}{|c|c|}
\hline Countries & Number of students \\
\hline Brazil & 11,419 \\
\hline Cape Verde & 4,332 \\
\hline Angola & 3,029 \\
\hline Guinea Bissau & 2,743 \\
\hline Ukraine & 2,626 \\
\hline Romania & 2,351 \\
\hline Sao Tome and Principe & 1,663 \\
\hline China & 1,223 \\
\hline Moldava & 1,027 \\
\hline United Kingdom & 707 \\
\hline
\end{tabular}

Although not included in the list above, several nationalities have had an exponential increase in only one year, namely Venezuela (+75.6\%), Nepal (+57\%) and Pakistan $(+29.1 \%)$, which will likely have an influence in the general school population if numbers continue to grow at a similar rate. There have been other nationalities, however, that have decreased, which may be due to many having meanwhile acquired Portuguese nationality. Nevertheless, the language and culture of the country of origin continues to play a central role at home. Considering these numbers, it becomes increasingly imperative that language teachers take into consideration their learners' different cultural and linguistic backgrounds, as a way to foment an easier process of integration as well as acknowledge everyone's background as equal. Moreover, since English is the most taught foreign language in the world, it is many of the times the only common shared language (even if at a basic level) (im)migrant/refugee learners share with their classmates and teacher. In view of this reality, it becomes more and more important that language educators be prepared to face these 
multilingual/multicultural environments, and teacher education programs play an important role in preparing well-informed educators. At the University of Lisbon, for example, there are two MA programs in ELT, one targeting primary EFL teachers (grades 3-4) and another targeting upper-basic and secondary EFL teachers (grades 7-12). Although both aim at educating and training future language teachers at two different educational levels, the issues so far discussed here are explored to a greater or lesser extent. In both programs there is no specific seminar on intercultural communication, ICA or ELF; however, these issues are discussed in other seminars, namely in Plural Didactic Approaches and English Didactics. In these classes STs have the opportunity to not only understand the political dimension of language education and the role of languages in human development, but they also learn how to teach English within the framework of plurilingual and intercultural education and plural didactic approaches. Furthermore, because their practicum is in the Lisbon metropolitan area, the schools where their teaching practice is done are, to a greater or lesser extent, multicultural and multilingual. By discussing and reflecting upon these issues at the university, they afterwards have the guidance and preparation to evaluate the group of students they will have at school, and adapt and/or develop the necessary teaching materials and resources. The following section provides some examples of activities and teaching resources developed by the STs, as well as their reflection about such experience and their learners' feedback. In comparison with what learners are usually accustomed to, the coursebook and other native-oriented materials (especially British and American), it is interesting to analyze their behavior and observations.

\subsection{Examples of activities/teaching resources developed}

Considering the primary EFL classroom, STs work with young A1 learners who are beginning their journey with English. In this case, the potential of exploring intercultural communication/ICA is more limited; however, young learners may be exposed right from the beginning to the reality of English language use - e.g. it is a language that belongs to everyone and not only the British or Americans. One ST took into consideration the multicultural nature of her third-grade class and tried to demonstrate this by using Voki (DIAS, 2017). Voki is a Web 2.0 educational tool that allows users to create their own customized talking avatar by recording their voice, uploading an audio file or using one of the available varieties on the website, which range from British, 
American, Australian, Scottish and Irish to South African and Indian English. As she had some learners from Indian and Chinese backgrounds, in addition to Caucasian avatars, the ST decided to also include an Indian and Chinese avatar, so the class could grasp how English is spoken by everyone (Figure 1). The Indian woman spoke Indian English (one of the varieties available on the website) and the Chinese man spoke American English.

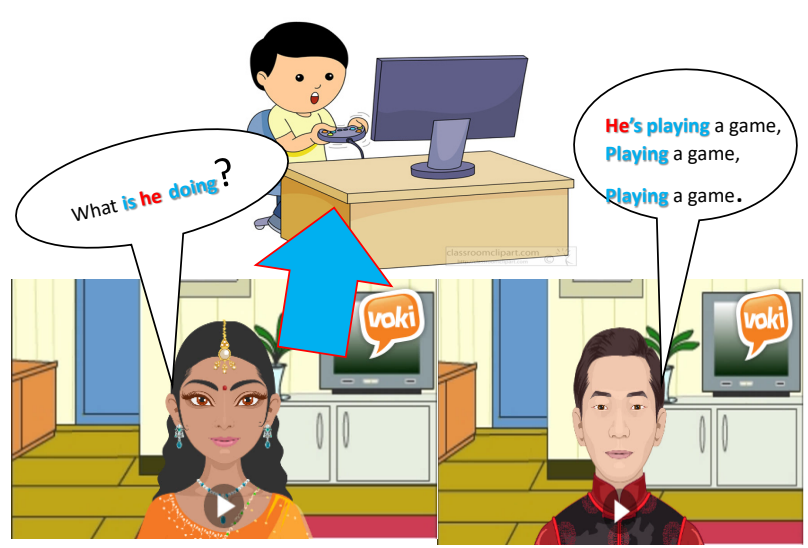

Figure 1. Example from Voki (DIAS, 2017)

The overall reaction of the class when seeing/listening to these two characters was to tease and make fun of them, especially when hearing Indian English. The reason for this may lie on the fact that the young learners had never seen or heard characters like these speaking in English. In fact, in their coursebook no examples of linguistic and cultural diversity were given, because the characters were animal cartoons. In view of this, the ST played an important role not only in introducing the group to the diversity of English use around the world, but also in making sure that those who came from other countries did not feel excluded or marginalized because of their cultural background.

In another case, one of the STs was originally from Moldava, but had been living in Portugal for several years. Having gone through the experience of moving to a new country and facing the reality of a new culture and language, she took her own experience into consideration when planning lessons for a third-grade class, which included learners from Eastern European countries, India, Angola and Cape Verde. In the several lessons taught, the ST took into account not only the reality/culture of the target language (e.g. British, American), but she also explored the Portuguese culture, her own Moldavian heritage and the culture of the other students in class (JAMACOCEAN, 2018). For instance, when discussing the topics "my world and the world of others" in 
her first class, the ST created a PowerPoint presentation where the young learners' diverse cultures were explored (Figure 2).

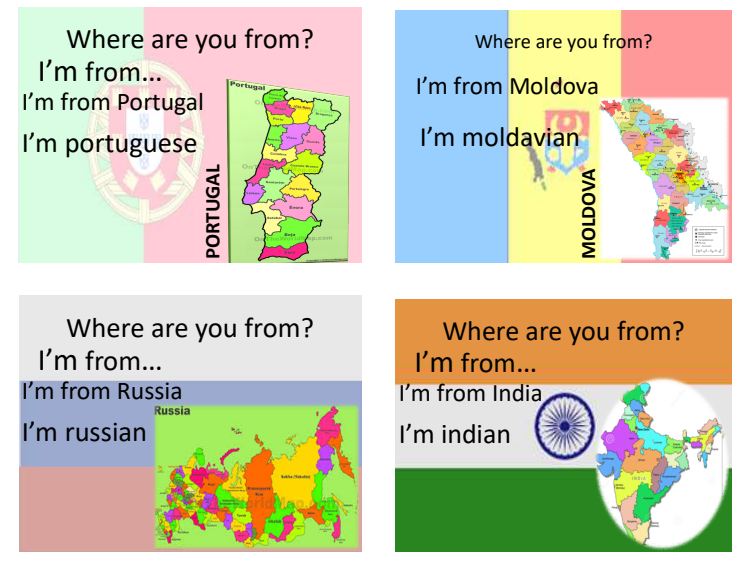

Figure 2. "My world and the world of others" PowerPoint (JAMACOCEAN, 2018)

The fact that she chose to present the learners' countries of origin helped her create a closer bond with the group and gain their trust. Furthermore, they were quite surprised to see their own cultures mentioned in class, because once again, this was something they had never encountered.

When Easter time came around, the ST chose to discuss Easter traditions around the world, including once more the learners' countries of origin (Figure 3). In addition to just mentioning them, she also explored how they differ from each other, how some countries may not celebrate Easter, and how important it is to respect others' traditions and values. Learners' reactions and discussions were very enthusiastic, as they became aware of how different cultures celebrate Easter, even wanting to visit these countries to get to know the cultures. The ST took this opportunity to also mention how English is many times the language of travel due to its global spread, which facilitates communication with others. 


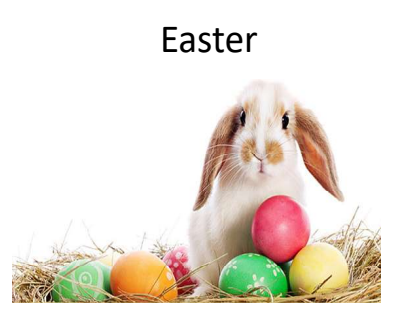

Easter in the USA

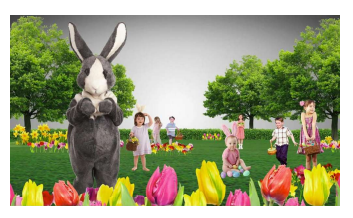

Easter in Portugal

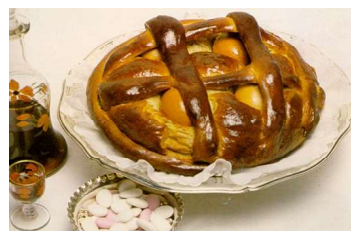

Easter in Russia, Ukraine, Romania

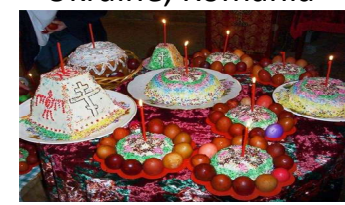

Figure 3. Example of Easter celebrations PowerPoint (JAMACOCEAN, 2018)

Although the two examples given are from a young learner context, it is evident that raising learners' awareness of cultural and linguistic diversity is crucial for their understanding of not only how English may sound differently depending on the speaker, but also how it may be used to promote discussion, awareness and acceptance of different people and cultures.

Considering an upper-basic education context, another ST assigned to a seventh-grade class decided to explore her learners' intercultural awareness and intercultural communicative competence (LOPES, 2018). This class had already had English from a primary level, so they were already able to communicate at a basic/intermediate level. The didactic unit taught was "home sweet home" and it also sought out to focus on reasoning and problem solving, interpersonal relations as well as self-development and autonomy. In order to develop these several aspects, the ST created a series of original teaching resources and acivities that would help stimulate learners' understanding and actual use of the language. For example, one of the initial resources developed included videos specifically made for the seventh grade class by former colleagues of the ST from a previous Erasmus experience (an interactive Skype session would have been the ideal scenario, however, the classroom did not have internet connection). In these videos, native and non-native speakers from several European countries introduced themselves and talked about their lives in the countries where they lived. These videos contributed not only to foment learners' awareness of the diversity in Europe, but also the opportunity to hear a variety of different accents. This was the first time the class had ever come into contact with other speakers of English who were speaking directly to them. As a result, they exhibited great interest and were quite inquisitive about how these people lived, and in the 
following lessons they would often refer to the videos, so to compare them with other cultural realities.

Another more interactive activity was the Key Pals Project that was created in cooperation with two other EFL teachers in Spain, one in Asturias and the other in Galicia, both working with students of the same age and grade. The students in these classes contacted each other via e-mail through English. As for the topics of the emails, they were mainly about personal knowledge, so they could get to know each other and compare their own cultural realities regarding whichever theme they wanted to discuss. Although there were some issues at times regarding communication, they were able to overcome these by paraphrasing, rewriting, code-switching, sending pictures, among other strategies. In the end, what at first began as a mandatory assignment with a certain structure, later became a voluntary exchange of emails in which students went on to discover their likes and dislikes, to discuss video games and their school lives, among other topics of their choice.

The practicum was an overall success, as learners were able to develop their intercultural communicative competence and become not only more interculturally aware of the differences/similarities between several countries, but also understand how to accept differences and sometimes divergent personal and cultural features.

\section{CONCLUDING REMARKS}

The increase in migrational flows have contributed to new and diverse communicative scenarios where a mulitiplicity of languages and cultures regularly come together. Consequently, as has been discussed here, the English language more often than not functions as the common language of choice for communication. Even within national contexts, the boom in tourism, the integration of global corperations/organizations and the internationalization of higher education, among other areas, have led to an increase in the use of English without having to travel abroad. The need to speak/write in English, both with native and non-native speakers across different domains, urges practitioners to rethink the English that is being taught. Instead of solely focusing on form, it is necessary to give greater attention to function, where issues related to ELF and intercultural awareness pave the way to successful intercultural communication.

The examples here given provide a broad overview of how ELF-related issues may be explored and developed across different educational levels. 
Although at a basic level it may be more challenging to develop certain types of activities, it is nevertheless important to broaden learners' understanding of how English is used differently across cultures, and how it can be used as a common language to discuss issues that promote tolerance, respect and acceptance. As for more intermediate/advanced learners, it is evident that actively engaging them in real language use allows them to develop the necessary skills and strategies to effectively communicate across different situations. In these cases, learning and using the language go hand in hand, and as Seidlhofer (2011, p. 198) mentions, the focus is on "learning how to language" - the ability to use diverse strategies to make sense, negotiate meaning and co-construct meaning.

Several other authors have likewise turned their attention to these issues and have provided their own practical examples of ELF-related lessons and materials in which learners' intercultural awareness and communication are encouraged, namely Guerra and Cavalheiro (2019), Kemaloglu-Er and Bayyurt (2018, 2019), Lee (2012), Lopriore and Vettorel (2019), Matsuda and Duran (2012), Siqueira and Matos (2019), Vettorel (2010, 2015), among others.

If teacher education programs, especially at a pre-service level, were to consider and explore these issues right from the beginning, future EFL teachers would gain not only a greater awareness of the issues involved, but also have the opportunity to reflect upon the challenges they may face in their teaching practices, and how they may lead to change in the classroom. If the aim is to educate successful intercultural language users, it is urgent that these concepts be introduced and developed in EFL classrooms.

\section{REFERENCES}

ALPTEKIN, C. Towards intercultural communicative competence in ELT. ELT Journal, v. 56, n. 1, p. 57-64, 2002.

BAKER, W. English as a lingua franca and intercultural communication. In: JENKINS, J., BAKER, W.; DEWEY, M. (Ed.). The Routledge Handbook of English as a Lingua Franca. London \& New York, 2018. p. 25-36.

BAKER, W. Culture and Identity through English as a Lingua Franca: rethinking concepts and goals in intercultural communication Berlin: De Gruyter Mouton, 2015.

BAKER, W. Intercultural awareness: modelling an understanding of cultures in intercultural communication through English as a lingua franca. Language and Intercultural Communication, v. 11, n. 3, p. 197-214, 2011. 
BAYYURT, Y.; SIFAKIS, N. Foundations of an EIL-aware teacher education. In: MATSUDA, A. (Ed.). Preparing Teachers to Teach English as an International Language. Bristol: Multilingual Matters, 2017. p. 3-18.

BYRAM, M. Teaching and Assessing Intercultural Communicative Competence. Clevedon: Multilingual Matters, 1997.

COUPLAND, N. Introduction: sociolinguistics in the global era. In: COUPLAND, N. (Ed.). Handbook of Language and Globalization. Malden, MA: Wiley-Blackwell, 2010. p. 127.

CRYSTAL, D. English as a Global Language. Cambridge: Cambridge University Press, 2003.

DEWEY, M. English as a lingua franca and globalisation: an interconnected perspective. International Journal of Applied Linguistics, v. 17, n. 3, p. 332-353, 2007.

DIAS, E. O Trabalho Colaborativo: Outra metodologia para motivar os alunos para a aprendizagem da língua inglesa no $1^{\underline{o}}$ ciclo do ensino básico. 2017. Master's Report. (Masters in English Language Teaching in the $1^{\text {st }}$ Cycle). Universidade de Lisboa, Lisboa.

FIRTH, A. The discursive accomplishment of normality: on 'lingua franca' English and conversation analysis. Journal of Pragmatics, vol. 26, p. 237-259, 1996.

GUERRA, L.; CAVALHEIRO, L. When the textbook is not enough: how to shape an ELF classroom? In: SIFAKIS, N. C.; TSANTILA, N. (Ed.). English as a Lingua Franca in EFL Contexts. Britsol: Multilingual Matters, 2019. p. 117-131.

JAMACOCEAN, G. A Abordagem Natural e o Ensino da Gramática de Língua Inglesa no 1ํㅜ CEB. 2018. Master's Report. (Masters in English Language Teaching in the $1^{\text {st }}$ Cycle). Universidade de Lisboa, Lisboa.

JENKINS, J. Repositioning English and multilingualism in English as a lingua franca. Englishes in Practice, v. 2, n. 3, p. 49-85, 2015.

JENKINS, J. English as a Lingua Franca: Attitude and Identity. Oxford: Oxford Unviersity Press, 2007.

JENKINS, J.; COGO, A.; DEWEY, M. Review of developments in research into English as a lingua franca. Language Teaching, v. 44, n. 3, p. 281-315, 2011.

KEMALOGLU-ER, E.; BAYYURT, Y. ELF-awareness in teaching and teacher education: explicit and implicit ways of integrating ELF into the English language classroom. In: SIFAKIS, N. C.; TSANTILA, N. (Ed.). English as a Lingua Franca in EFL Contexts. Britsol: Multilingual Matters. 2019. p. 159-174. 
KEMALOGLU-ER, E.; BAYYURT, Y. ELF-aware pre-service teacher education: teaching practices and reflections from Turkey. In: CAVALHEIRO, L. (Ed.). Preparing English Language Teachers for Today's Globalized World. Vila Nova de Famalicão: Húmus, 2018. p. 47-64.

KRAMSCH, C. Intercultural communication. In: CARTER, R.; NUNAN, D. (Ed.). The Cambridge Guide to Teaching English to Speakers of Other Languages. Cambridge: Cambridge University Press, 2001. p. 201-206.

LEE, H. World Englishes in a high school English class: a case from Japan. In:

LEUNG, C.; LEWKOWICZ, J. English language teaching: pedagogic reconnection with the social dimension. In: JENKINS, J.; BAKER, W.; DEWEY, M. (Ed.). The Routledge Handbook of English as a Lingua Franca. London \& New York, 2018. p. 61-73.

LLURDA, E. English language teachers and ELF. In: JENKINS, J.; BAKER, W.; DEWEY, M. (Ed.). The Routledge Handbook of English as a Lingua Franca. London \& New York, 2018. p. 518-528.

LOPES, A. P. Introducing Intercultural Awareness and Intercultural Communicative Competence for English Learners. 2018. Master's Report. (Masters in English Language Teaching and Foreign Language). Universidade de Lisboa, Lisboa.

LOPRIORE, L. Revisiting language education within an ELF embedded approach: merging practices in ELT and CLIL teacher education courses. In: CAVALHEIRO, L. (Ed.). Preparing English Language Teachers for Today's Globalized World. Vila Nova de Famalicão: Húmus, 2018. p. 65-80.

LOPRIORE, L.; VETTOREL, P. Perspectives in WE- and ELF-informed ELT materias in teacher education. In: SIFAKIS, N. C.; TSANTILA, N. (Ed.). English as a Lingua Franca in EFL Contexts. Britsol: Multilingual Matters, 2019. p. 97-116.

MCKAY, S. L.; BOKHORST-HENG, W. D. International English in its Sociolinguistic Contexts: Towards a socially sensitive EIL pedagogy. London: Routledge, 2008.

MATSUDA, A.; DURAN, C. S. EIL activities and tasks for traditional English classrooms. In: MATSUDA, A. (Ed.). Principles and Practices of Teaching English as an International Language. Bristol: Multilingual Matters, 2012. p. 201-237.

MATSUDA, A. (Ed.). Principles and Practices of Teaching English as an International Language. Bristol: Multilingual Matters, 2012. p. 154-168.

MAURANEN, A. Exploring English asa Lingua Franca. Cambridge: Cambridge University Press, 2012. 
MAURANEN, A. Conceptualising ELF. In: JENKINS, J.; BAKER, W.; DEWEY, M. (Ed.). The Routledge Handbook of English as a Lingua Franca. London \& New York, 2018. p. 7-24.

OLIVEIRA, C. R.; GOMES, N. Indicadores de Integração de Imigrantes - Relatório Estatístico Anual 2018. Lisboa: Alto Comissariado para as Migrações, 2018.

SCOLLON, R.; SCOLLON, S. W. Discourse and intercultural communication. In: SCHIFFRIN, D.; TANNEN, D.; HAMILTON, H. (Ed.) The Handbook of Discourse Analysis. Oxford: Blackwell, 2001. p. 538-547.

SEIDLHOFER, B. Understanding English as a Lingua Franca. Oxford: Oxford University Press, 2011.

SIFAKIS, N. Challenges in teaching ELF in the periphery: the Greek context. ELT Journal, v. 63, n. 3, p. 230-237, 2009.

SIFAKIS, N. C.; BAYYURT, Y. Insights from ELF and WE in teacher training in Greece and Turkey. World Englishes, v. 34, n. 3, p. 471-484, 2015.

SIQUEIRA, S. For an intercultural teacing of English as a lingua franca: notes from a Brazilian experience. In: CAVALHEIRO, L. (Ed.). Preparing English Language Teachers for Today's Globalized World. Vila Nova de Famalicão: Húmus, 2018. p. 81-100.

SIQUEIRA, S.; MATOS, J. V. G. ELT materials for basic education in Brazil: has the time for an ELF-aware practice arrived? In: SIFAKIS, N. C.; TSANTILA, N. (Eds.). English as a Lingua Franca in EFL Contexts. Britsol: Multilingual Matters, 2019. p. 132156.

SIQUEIRA, S. English as a lingua franca: for a critical intercultural pedagogy. In: LOPRIORE, L.; GRAZZI, E. (Ed.). Intercultural Communication: New perspectives from ELF. Roma: Roma Tres Press, 2016. p. 189-209.

VETTOREL, P. Primary School Teachers' Perceptions: Englishes, ELF and Classroom Practices-Between 'Correctness' and 'Communicative Effectiveness.' In: VETTOREL, P. (Ed.). New Frontiers in Teaching and Learning English. Newcastle-upon-Tyne: Cambridge Scholars, 2015. p. 129-155.

VETTOREL, P. English(es), ELF, Xmas and Trees: Intercultural Communicative Competence and English as a Lingua Franca in the Primary Classroom. Perspectives - $A$ Journal of TESOL Italy, v. 37, n. 1, p. 25-52, 2010.

ZHU, H. Exploring Intercultural Communication: Language in action. Abingdon: Routledge, 2014. 


\section{Lili Cavalheiro}

Lili Cavalheiro has a PhD in Applied Linguistics from the School of Arts and Humanities of the University of Lisbon, where she also teaches English and is involved in the Masters in English Language Teaching. She is likewise a part of the Linguistics: language, culture and society research group at ULICES - University of Lisbon Centre for English Studies. Her research interests include English as a Lingua Franca, English Language Teaching, Teacher Education, Materials Development and Intercultural Communication, areas in which she has published and presented papers at a national and international level.

Nota do editor:

Artigo submetido para avaliação em: 15/03/2019.

Aprovado em sistema duplo cego em: 12/11/2019. 